\title{
Alginate Bioconjugate and Graphene Oxide in Multifunctional Hydrogels for Versatile Biomedical Applications
}

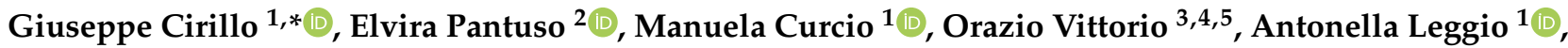 \\ Francesca Iemma ${ }^{1}$, Giovanni De Filpo ${ }^{6}$ (i) and Fiore Pasquale Nicoletta ${ }^{1}$ (i)
}

1 Department of Pharmacy, Health and Nutritional Sciences, University of Calabria, 87036 Rende (CS), Italy; manuela.curcio@unical.it (M.C.); antonella.leggio@unical.it (A.L.); francesca.iemma@unical.it (F.I.); fiore.nicoletta@unical.it (F.P.N.)

2 National Research Council of Italy (CNR) - Institute on Membrane Technology (ITM), 87036 Rende (CS), Italy; e.pantuso@itm.cnr.it

3 Children's Cancer Institute, Lowy Cancer Research Centre, UNSW Sydney, Sydney, NSW 2031, Australia; OVittorio@ccia.unsw.edu.au

4 School of Women's and Children's Health, Faculty of Medicine, UNSW Sydney, Sydney, NSW 2052, Australia

5 ARC Centre of Excellence for Convergent BioNano Science and Technology, Australian Centre for NanoMedicine, UNSW Sydney, Sydney, NSW 2052, Australia

6 Department of Chemistry and Chemical Technologies, University of Calabria, 87036 Rende (CS), Italy; giovanni.defilpo@unical.it

* Correspondence: giuseppe.cirillo@unical.it; Tel.: +39-098-449-3208

Citation: Cirillo, G.; Pantuso, E.; Curcio, M.; Vittorio, O.; Leggio, A.; Iemma, F.; De Filpo, G.; Nicoletta, F.P. Alginate Bioconjugate and Graphene Oxide in Multifunctional Hydrogels for Versatile Biomedical Applications. Molecules 2021, 26, 1355. https:// doi.org/10.3390/molecules26051355

Academic Editor: Alejandro Sosnik

Received: 2 February 2021

Accepted: 28 February 2021

Published: 3 March 2021

Publisher's Note: MDPI stays neutral with regard to jurisdictional claims in published maps and institutional affiliations.

Copyright: (c) 2021 by the authors. Licensee MDPI, Basel, Switzerland. This article is an open access article distributed under the terms and conditions of the Creative Commons Attribution (CC BY) license (https:// creativecommons.org/licenses/by/ $4.0 /)$.

\begin{abstract}
In this work, we combined electrically-conductive graphene oxide and a sodium alginatecaffeic acid conjugate, acting as a functional element, in an acrylate hydrogel network to obtain multifunctional materials designed to perform multiple tasks in biomedical research. The hybrid material was found to be well tolerated by human fibroblast lung cells (MRC-5) (viability higher than $94 \%$ ) and able to modify its swelling properties upon application of an external electric field. Release experiments performed using lysozyme as the model drug, showed a $\mathrm{pH}$ and electro-responsive behavior, with higher release amounts and rated in physiological vs. acidic $\mathrm{pH}$. Finally, the retainment of the antioxidant properties of caffeic acid upon conjugation and polymerization processes (Trolox equivalent antioxidant capacity values of 1.77 and 1.48, respectively) was used to quench the effect of hydrogen peroxide in a hydrogel-assisted lysozyme crystallization procedure.
\end{abstract}

Keywords: hybrid hydrogels; controlled drug delivery; protein crystallization; lysozyme

\section{Introduction}

Hydrogels are valuable materials in biomedicine, including tissue engineering, drug delivery, and discovery, by virtue of their toughness, softness, flexibility, and elasticity [1,2] More importantly, the significant wetting tendency of their hydrophilic and porous surfaces are interesting features in the preparation of biomaterials suitable for different applications, including the fabrication of either release devices or templates for crystallization of biologically relevant proteins [3]. The possibility of designing effective therapeutic strategies via modulating the amount and rate of release, offers the possibility to match different therapeutic needs with a single device $[4,5]$. In addition, the determination of complex molecular structures through X-ray diffraction (XRD) analyses is a key finding for elucidating the molecular basis of human pathologies and discovering new therapeutic targets [6-8].

The functional features and chemical composition of hydrogels can be finely tuned using a combination of components with different physical or chemical properties at the nanometer or molecular level [9] and these so-called hybrid hydrogels show performances superior to those of individual components $[10,11]$. The high biocompatibility, low-immunogenicity, biodegradability, chemical versatility, and natural abundance of 
polysaccharides and proteins can be coupled with significant stability, high purity, and absence of variability between batches (e.g., molecular weight) of synthetic polymers, for the formation of versatile natural/synthetic hybrid materials [12,13]. Moreover, the incorporation of inorganic components (e.g., carbon nanostructures, CNs) via covalent or non-covalent interactions [14,15] results in organic/inorganic hybrid materials with improved properties (e.g., thermal and mechanical stability) for long-term applications [16,17]. In addition, the electrical conductivity of $\mathrm{CNs}$ is retained, and therefore the hydrogel properties (e.g., water uptake and affinity for a loaded therapeutic agent) can be modulated by applying an external electric field $[18,19]$.

More recently, it has been proven that functional hydrogels with antioxidant properties can be synthesized by the conjugation of active molecules (e.g., polyphenols) to polymer chains [20,21], offering interesting solutions for mitigating oxidative stress. This is a significant challenge in both drug delivery and discovery, since the possibility to reduce oxidative damages is a key property for any material designed for interactions with living tissues [22,23], as well as in X-ray crystallography, where the oxidation of the protein sample in a crystallization droplet can lead to failure of the crystallization process [24,25].

In this work, we synthesized a multifunctional hybrid hydrogel film (HACG) obtained by co-polymerization of acrylate monomers in the presence of graphene oxide (GO), and a new sodium alginate-caffeic acid conjugate (AlgCF). The performance of HACG in biomedical applications was evaluated by exploring two main issues, namely the fabrication of a smart delivery vehicle able to modulate the release of bioactive macromolecules by electric stimulation, and the obtainment of a template able to confine and concentrate macromolecules in its porous structure, thus, facilitating crystallization under oxidation conditions.

\section{Results and Discussion}

In this study, the proposed multifunctional hybrid hydrogel (i.e., HACG) is composed of an acrylate network where AlgCF conjugate and graphene oxide (GO) are inserted as functional components, conferring peculiarities suitable for applications in biomedicine.

Acrylate polymers have been extensively studied for biomedical applications, due to their high biocompatibility and chemical versatility [26,27].

Sodium alginate (Alg) is a natural polysaccharide with $\beta$-D-mannuronic acid and $\alpha$-Lguluronic acid repeating units [28], which shows the typical advantages of polysaccharides for biomedical applications, together with a high degradation rate allowing applications such as cell encapsulating and wound healing devices [29-31], as well as a coadjuvant in protein crystallization $[32,33]$.

Caffeic acid (CF), which belongs to the hydroxycinnamic acids with a phenylpropenoic acid structure containing a 3,4-dihydroxylated aromatic ring attached to a carboxyl group through a trans-ethylene wire, is a powerful antioxidant that can both scavenge and inhibit the generation of free radical species [34,35]. The hexagonal lattice structure of hybridized $\mathrm{sp}^{2}$ carbon atoms of GO is responsible for superior electrical conductivity and ability to interact with bioactive molecules of either low or high molecular weight via $\pi-\pi$, hydrophobic, electrostatic interactions, and hydrogen bonding [36,37]. Furthermore, due to the presence of oxygen-rich functionalities (e.g., epoxide, phenolic, hydroxyl, and carboxylic groups), GO can be covalently incorporated in hydrogel networks via condensation/polymerization methods, obtaining hybrid hydrogels for drug delivery, biosensors, and tissue scaffold applications [38-40].

The synthetic procedure involved the synthesis of the AlgCF conjugate, using immobilized laccase as a biocatalyst, and its subsequent co-polymerization in the presence of GO and acrylate monomer mixture, consisting of hydroxyethyl acrylate (HEA) and polyethylene glycol dimethacrylate 750 (PEGDMA) as plasticizing and crosslinking monomers, respectively (Figure 1). 
<smiles>C=C(C)C(=O)NC(=O)CCCOC(=O)C(=C)C</smiles>

PEGDMA<smiles>C=CC(=O)OCCO</smiles>

HEA

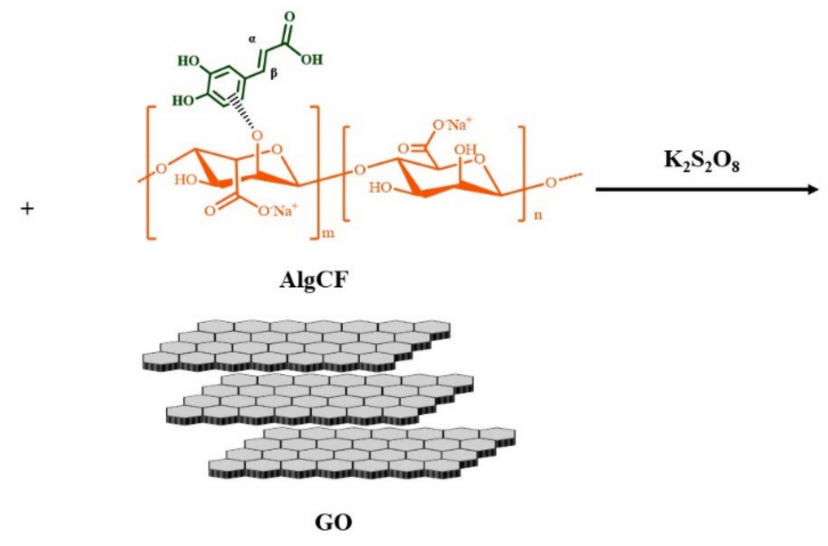

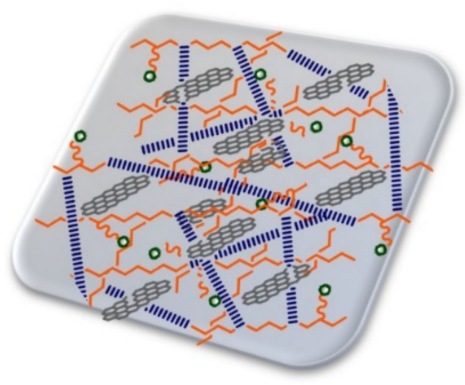

HACG

Figure 1. Schematic representation of the synthesis of multifunctional hybrid hydrogels.

\subsection{Synthesis and Characterization of Sodium Alginate-Caffeic Acid Conjugate}

$\mathrm{Alg} C \mathrm{~F}$ conjugate was synthesized by means of laccase chemistry via a heterogeneous catalysis approach previously developed for the conjugation of different polyphenolic compounds to polysaccharide and protein materials [41]. This methodology can be conducted in a totally green environment, ensuring the absence of any trace of toxicity and a high purity of the final product, which are key advantages for any material designed for biomedical applications. The experimental procedure involved immobilization of laccase into acrylate polymer networks. Laccase promotes a one-electron oxidation of caffeic acid (CF) $[42,43]$ favoring the coupling by reactive groups in the Alg side chains, although the actual reaction mechanism is not well understood [44].

After purification by dialysis procedure to ensure removal of any trace of unconjugated $\mathrm{CF}$, chemical characterization of AlgCF was performed by means of ${ }^{1} \mathrm{H}-\mathrm{NMR}$ and calorimetric analyses to assess the effective conjugation and the effect of $\mathrm{CF}$ on the thermal properties of the conjugate, respectively, while static light scattering measurements were used to estimate the average molecular weight $(\mathrm{Mw})$ of $\mathrm{Alg}$ and $\mathrm{AlgCF}$.

The ${ }^{1} \mathrm{H}-\mathrm{NMR}$ spectra of $\mathrm{Alg}$ and $\mathrm{AlgCF}$ are reported in Figure 2. Signals in the range of 4.2-5.1 ppm were assigned to the Alg and AlgCF anomeric protons of $\beta$-D-mannuronic acid and $\alpha$-L-guluronic acid repeating units, and to the methine protons adjacent to the carboxyl groups, the resonance of the remaining protons of sugar rings fall in between 3.2 and $4.1 \mathrm{ppm}[45,46]$. In the AlgCF spectrum, new signals not recorded in the spectrum of native Alg and assigned to $\mathrm{CF}$ residues were detected and considered to be experimental evidence for the effective formation of the conjugate, namely the olefinic protons at around $6.2(\alpha)$ and $7.4(\beta)$ ppm and the aromatic protons in the range of 6.6-7.3 ppm [47].

The differential scanning calorimetry (DSC) thermograms of Alg and AlgCF are shown in Figure 3.

Alg showed the typical DSC curve of polysaccharide materials with hydroxyl and carboxyl functionalities in the repeating units, with a first transition at $95^{\circ} \mathrm{C}$, assigned to the evaporation of moisture from the polymer [48], and a broad exothermic at $243^{\circ} \mathrm{C}$, expressing the formation of $\mathrm{CO}_{2}, \mathrm{CH}_{4}$, and $\mathrm{H}_{2} \mathrm{O}$ from polysaccharide chains due to decomposition at a higher temperature [49]. The decomposition involves different kinds of chemical reactions, including depolymerization, elimination of oxygen-rich functionalities in the side chains, chain scissions, recombination, and cross-linking, which can be accelerated in the presence of radical species [50]. 


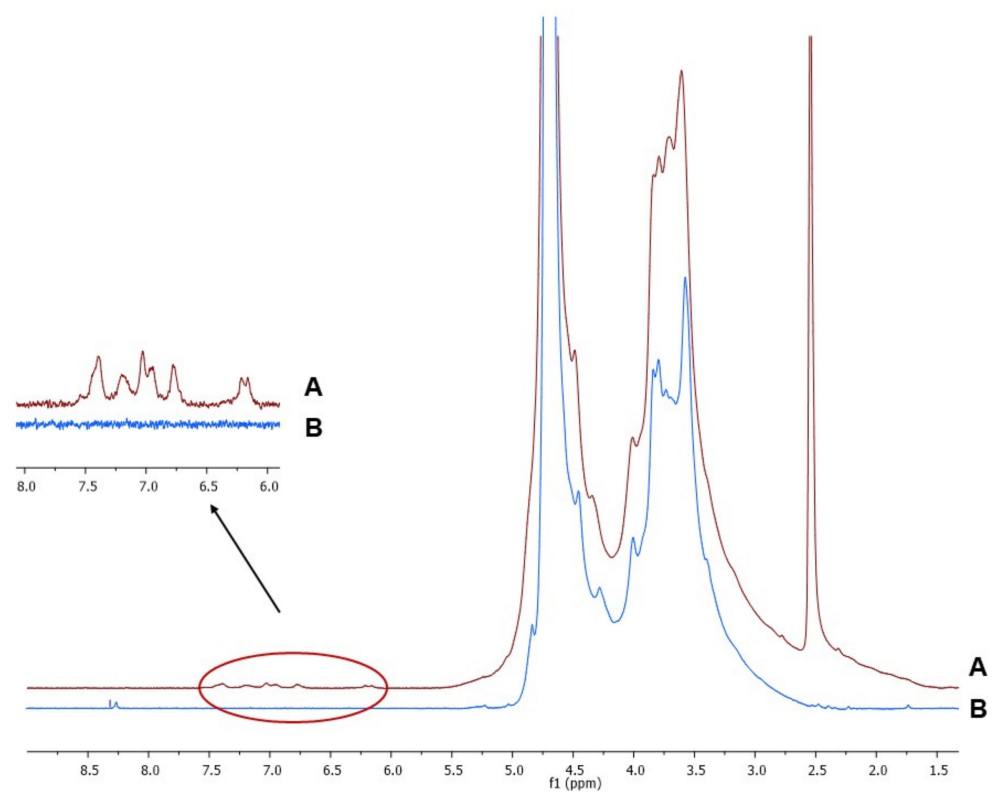

Figure 2. ${ }^{1} \mathrm{H}-\mathrm{NMR}$ of purified (A) sodium alginate-caffeic acid conjugate (AlgCF) and (B) sodium alginate $(\mathrm{Alg})$ in $\mathrm{D}_{2} \mathrm{O}$.

The covalent conjugation with CF moieties was expected to enhance the thermal stability of the AlgCF conjugate, as confirmed by the shift of the exothermal degradation peak to higher temperature values $\left(251^{\circ} \mathrm{C}\right)$.

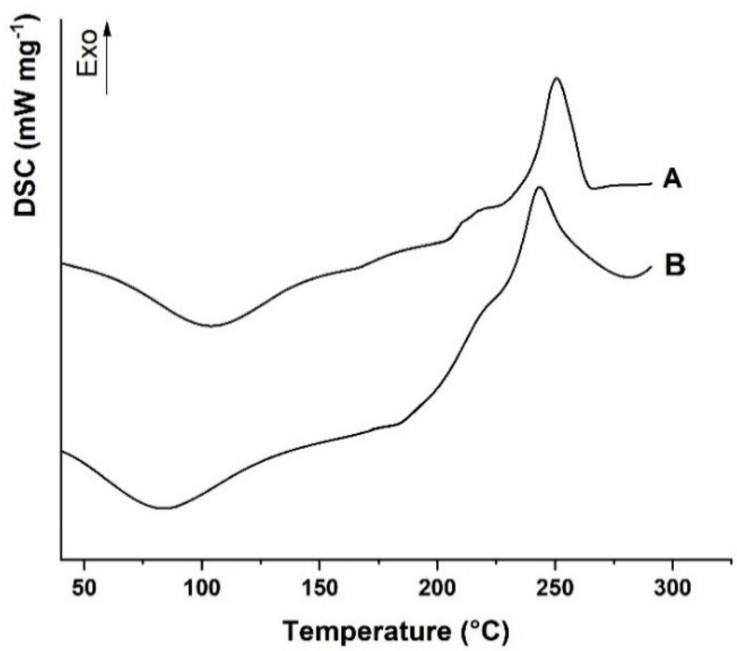

Figure 3. Differential scanning calorimetry (DSC) thermograms of (A) AlgCF and (B) Alg. Curves were vertically shifted for readability.

The results of the molecular weight determination (145 $\pm 15 \mathrm{kDa}$ for both Alg and $\mathrm{Alg} \mathrm{CF}$ ) indicated that the molecular weight did not significantly change upon conjugation of $\mathrm{CF}$, suggesting a functionalization degree below $10 \%$.

\subsection{Synthesis and Characterization of Hybrid Hydrogels}

We previously reported on the possibility of covalently incorporating either carbon nanostructures (carbon nanotubes and graphene oxide) or polyphenol conjugates into acrylate hydrogels via free radical polymerization, obtaining functional materials suitable for drug delivery and healing applications [23,51].

Here, following the same synthetic approach, AlgCF and GO were simultaneously incorporated into a hydrogel network (HACG) based on HEA and PEGDMA, optimizing 
the reagent ratio (11.5\% AlgCF, 1.15\% GO, 42.30\% HEA, and 45.05\% PEGDMA, $w / w)$ in order to maximize the amount of incorporated GO and $\mathrm{AlgCF}$ and the water affinity, avoiding, at the same time, hydrogel breakage upon drying. A lower amount of plasticizing and crosslinker, indeed, carried out to fragile hydrogels, while higher amounts of PEGDMA were responsible for less swellable materials.

Control samples, HAG and HAC, were synthesized by replacing AlgCF with native $\mathrm{Alg}$ and not inserting GO in the pre-polymerization feed, respectively, to determine the influence of either CF or GO moieties on the device performance. In detail, HAC was used to highlight the electro-responsivity in the release experiments, while HAG was useful in the crystallization experiments.

HACG was characterized by a rough and porous surface, as per morphological investigation (Figure 4a), while human fibroblast lung cells (MRC-5) viability values higher than $94.0 \% \pm 2.5$ upon incubation of HACG ( 0.1 to $1.0 \mathrm{mg} \mathrm{mL}^{-1}$ concentration range, Figure $4 \mathrm{~b}$ ), confirmed its biocompatibility. These cells, indeed, are widely recognized as an in vitro model to check the toxicity of different kinds of biologically oriented materials, due to their specific metabolic features and high sensibility to almost any types of chemicals [52].

Similar results were observed when HAG and HAC were used.

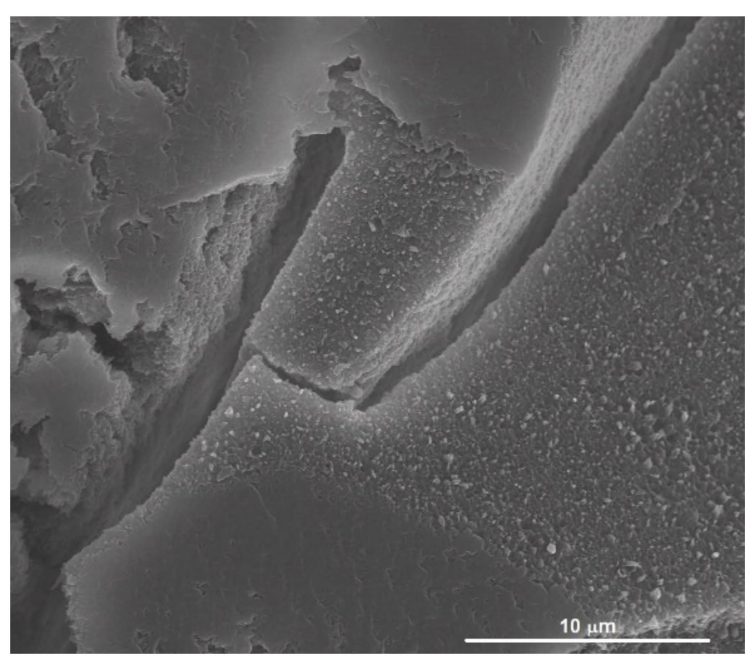

(a)

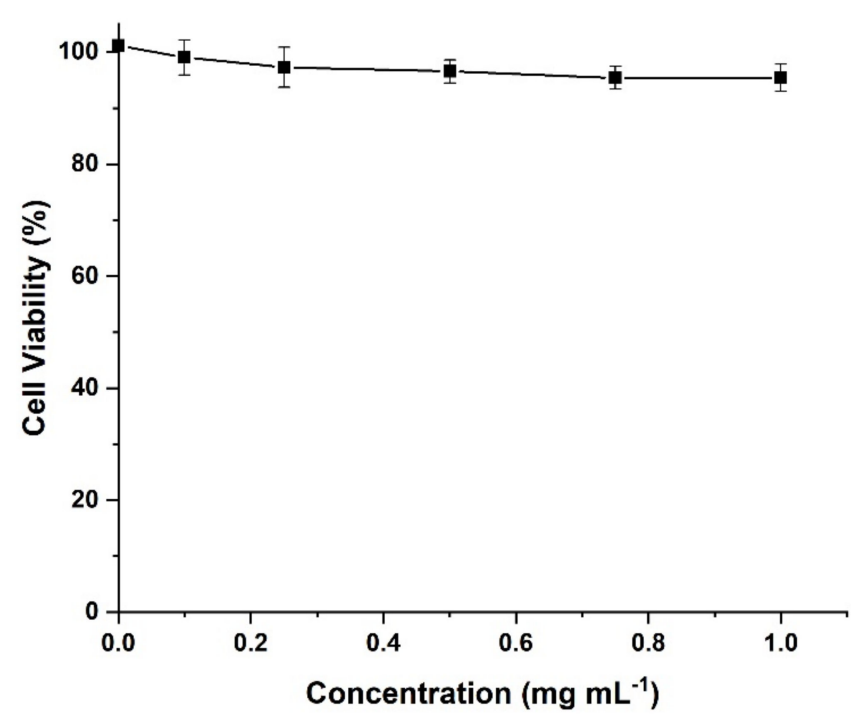

(b)

Figure 4. (a) SEM image of multifunctional hybrid hydrogel film (HACG) sample; (b) Human fibroblast lung cells (MRC-5) viability after $72 \mathrm{~h}$ incubation with pulverized HACG sample suspended in Dulbecco's modified Eagle's medium (DMEM) + FCS $10 \%$.

Swelling experiments were performed in order to evaluate the HACG water affinity, a required key property for materials proposed for interactions with living tissues. Due to the chemical features of $\mathrm{Alg}$ and $\mathrm{GO}$, such determination was performed in two $\mathrm{pH}$ conditions, mimicking an acidic ( $\mathrm{pH}$ 5.5) and a physiological environment (pH 7.4), respectively, and in the presence or absence of electric stimulation at 12, 24, and $48 \mathrm{~V}$ (Table 1).

From the data in Table 1, it is evident that the carboxylic functionalities in both Alg and GO were responsible for the higher water absorption properties at $\mathrm{pH} 7.4$ vs. $\mathrm{pH} 5.5$, because of their different ionization statuses, carrying out electrostatic repulsion between the carboxylate anions (pKa of $\mathrm{COOH}$ in the range 4-5) [53]. The effect of applying an external voltage on the swelling profile can be highlighted by comparing the swelling of blank and hybrid hydrogels and introducing the swelling ratio parameter $S_{r}$, according to Equation (1):

$$
S_{r}=\frac{W R_{v}-W R_{0}}{W R_{0}} \times 100
$$


where $W R_{v}$ and $W R_{0}$ are the swelling degrees at the selected voltage $(12,24$, and $48 \mathrm{~V})$ and $0 \mathrm{~V}$, respectively.

Table 1. Swelling behavior at equilibrium of blank and hybrid hydrogels in different $\mathrm{pH}$ and voltage conditions.

\begin{tabular}{|c|c|c|c|c|}
\hline Sample & $\mathrm{pH}$ & Voltage & WR (\%) & $S_{r}=\frac{W R_{v}-W R_{0}}{W R_{0}} \times 100$ \\
\hline \multirow{4}{*}{ HAC } & \multirow{4}{*}{5.5} & 0 & $332 \pm 3.1$ & -- \\
\hline & & 12 & $334 \pm 3.3$ & 0.6 \\
\hline & & 24 & $337 \pm 2.9$ & 1.5 \\
\hline & & 48 & $341 \pm 3.4$ & 2.7 \\
\hline \multirow{4}{*}{ HACG } & \multirow{4}{*}{5.5} & 0 & $351 \pm 2.8$ & - - - \\
\hline & & 12 & $401 \pm 3.0$ & 14.2 \\
\hline & & 24 & $578 \pm 3.2$ & 64.7 \\
\hline & & 48 & $554 \pm 3.1$ & 57.8 \\
\hline \multirow{4}{*}{ HAC } & \multirow{4}{*}{7.4} & 0 & $605 \pm 2.7$ & -- \\
\hline & & 12 & $611 \pm 2.9$ & 1.0 \\
\hline & & 24 & $617 \pm 2.7$ & 2.0 \\
\hline & & 48 & $620 \pm 2.8$ & 2.5 \\
\hline \multirow{4}{*}{ HACG } & \multirow{4}{*}{7.4} & 0 & $696 \pm 3.1$ & -- \\
\hline & & 12 & $805 \pm 3.0$ & 15.7 \\
\hline & & 24 & $849 \pm 2.7$ & 22.0 \\
\hline & & 48 & $835 \pm 2.8$ & 20.0 \\
\hline
\end{tabular}

As reported in the literature, this effect can be explained as the result of two main phenomena, i.e., ionization of the $\mathrm{COOH}$ functionalities and generation of an osmotic pressure between the inner and outer portions of the hydrogel network, due to the rearrangement of mobile ions moving to the opposite electrodes [54].

The swelling degree of HAC was weakly affected by the applied voltages (Sr below 2.7 at both $\mathrm{pH}$ values), while the $\mathrm{GO} \mathrm{sp}{ }^{2}$ carbon layer conferred significant electro-responsivity to HACG, being more evident at acidic than physiological conditions. At $\mathrm{pH} 5.5$, the larger number of available undissociated $\mathrm{COOH}$ could be effectively ionized by the electric stimulation, resulting in an increased electrostatic repulsion, and thus higher hydrogel swelling. On the contrary, at $\mathrm{pH} 7.4$, a more significant number of $\mathrm{COO}^{-}$groups was already formed even in the absence of the external voltage, and lower Sr values were recorded. Furthermore, although the ionization of $\mathrm{COOH}$ groups was the main driving force at 12 and $24 \mathrm{~V}$, osmotic pressure started to be predominant at higher voltages $(48 \mathrm{~V})$, carrying out a more evident network deformation and reduced $\mathrm{Sr}$ values $\left(\mathrm{Sr}_{48} 57.8\right.$ and 20.0 vs. $\mathrm{Sr}_{24} 64.7$ and 22.0 at $\mathrm{pH} 5.0$ and 7.4, respectively).

\subsection{Lysozyme Loading and In Vitro Release Studies}

Electric stimulation is a valuable tool for fine tuning the delivery of therapeutic agents, in terms of both total release amount and rate, because of the possibility to modulate key parameters such as voltage intensity and duration [55]. Here, we explored the possibility of using HACG as a carrier for lysozime (LZM), a naturally occurring protein (14.4 kDa molecular weight) that shows high biocompatibility and antibacterial activities through degradation of cell walls of Gram-positive bacteria [56], and is widely proposed as a bioactive component of hydrogel systems for tissue engineering applications [57].

LZM was loaded into HAC and HACG through a soaking-drying procedure to reach the same LZM to carrier ratio in both cases $(6.0 \%)$. The loading of LZM on HAC is the result of the formation of strong electrostatic interactions between the negatively charged carboxylic functionalities of AlgCF (pKa between 4 and 5) and positively charged groups on LZM (isoelectric point = 11) [58]. 
Release experiments were recorded as a function of $\mathrm{pH}$ variation, selecting the physiological (7.4) and the acidic (5.5) $\mathrm{pH}$ value of infection site where LZM is planned to elicit its antimicrobial activity.

For a more detailed comparison of the behavior of blank and hybrid hydrogels, experimental data were analyzed by applying four different mathematical models, considering the release kinetics as zero order (Equation (2)), first-order (Equation (3)) kinetics, or a combination of Fickian and anomalous diffusion (Equations (4) and (5)) [59].

The first model is the zero-order kinetic expressed by Equation (2) as follows:

$$
\frac{M_{t}}{M_{0}}=K_{0} t
$$

where $\mathrm{M}_{\mathrm{t}}$ is the amount of released LZM at time $\mathrm{t}, \mathrm{M}_{0}$ the total amount of loaded LZM, $\mathrm{K}_{0}$ is the zero-order kinetic constant, and $\mathrm{t}$ the time of release.

Equation (3) describes a first-order kinetic as follows:

$$
\frac{M_{t}}{M_{0}}=a\left(1-e^{-K_{1} t}\right)
$$

$\mathrm{K}_{1}$ is the first-order kinetic constant, $\mathrm{t}$ is the time of the release, and a is the release coefficient.

The third model is given by the Ritger-Peppas Equation (4):

$$
\frac{M_{t}}{M_{0}}=K t^{n}
$$

where $\mathrm{K}$ is the kinetic constant, $\mathrm{t}$ is the time of the release, and $\mathrm{n}$ is the coefficient indicating the mechanism of the release; $\mathrm{n} \leq 0.43$ indicates a Fickian diffusion mechanism, $\mathrm{n}=0.84 \mathrm{a}$ Case II transport, and $0.43<\mathrm{n}<0.85$ anomalous transport mechanism.

The last model is described by the Peppas-Sahlin Equation (5):

$$
\frac{M_{t}}{M_{0}}=K_{F} t^{1 / 2}+K_{a} t
$$

where $\mathrm{K}_{\mathrm{F}}$ and $\mathrm{K}_{\mathrm{a}}$ are the kinetic constants of Fickian and anomalous diffusion, respectively.

The LZM release profiles from HAC at acidic $\mathrm{pH}$ are depicted in Figure 5.

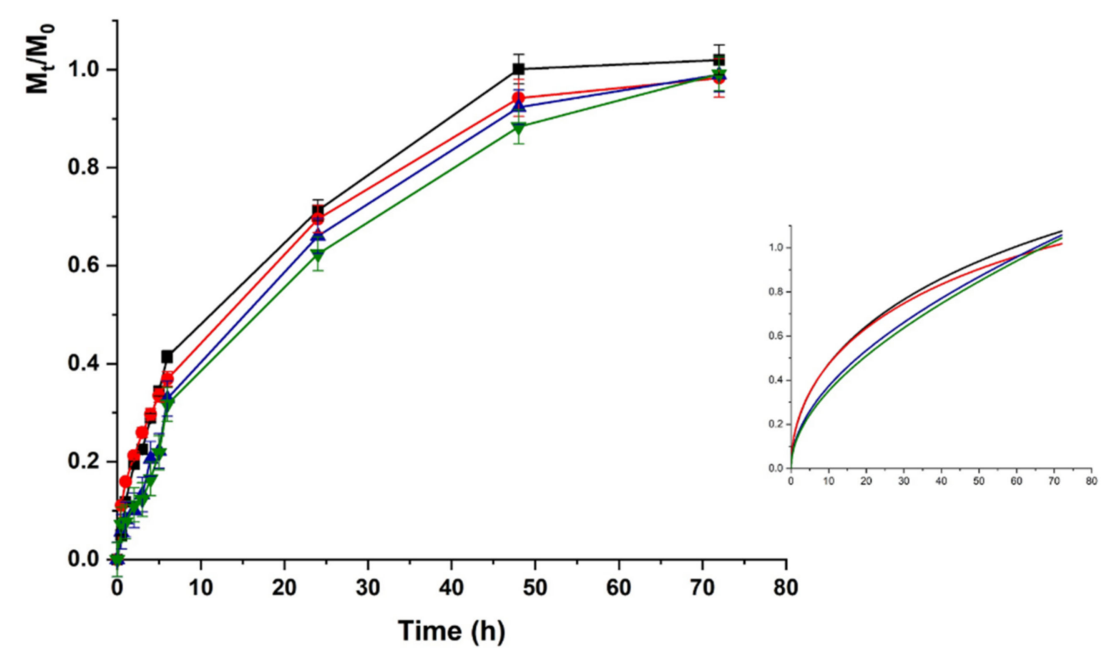

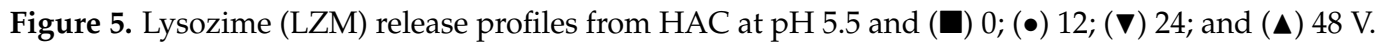
Inset: Fitting curve by Equation (5).

Upon $\mathrm{pH}$ increase to 7.4 (Figure 6), the LZM release from HAC can be explained as the result of two opposite phenomena modulating the protein to hydrogel interactions. 
The LZM ionization equilibrium moved to the undissociated form, thus, promoting the release, while a prevalence of dissociated $\mathrm{COOH}$ functionalities occurred on the polymer network, enhancing the LZM affinity to the hydrogel through a higher density of negative charges. The prevalent phenomenon was the modification of ionized LZM concentration at equilibrium, resulting in an increased release at $\mathrm{pH} 7.4$ vs. 5.5. The lower interactions between LZM and hydrogels at $\mathrm{pH} 7.4$ were responsible for release kinetics, better described by first-order kinetics (higher $\mathrm{R}^{2}$ values in Table 2), while at $\mathrm{pH} 5.5$ Ritger-Peppas and Peppas-Sahlin diffusion models (Equations (4) and (5)) better fitted the experimental data. Thus, the analysis of data at $\mathrm{pH} 5.5$ was performed by using Equation (5).

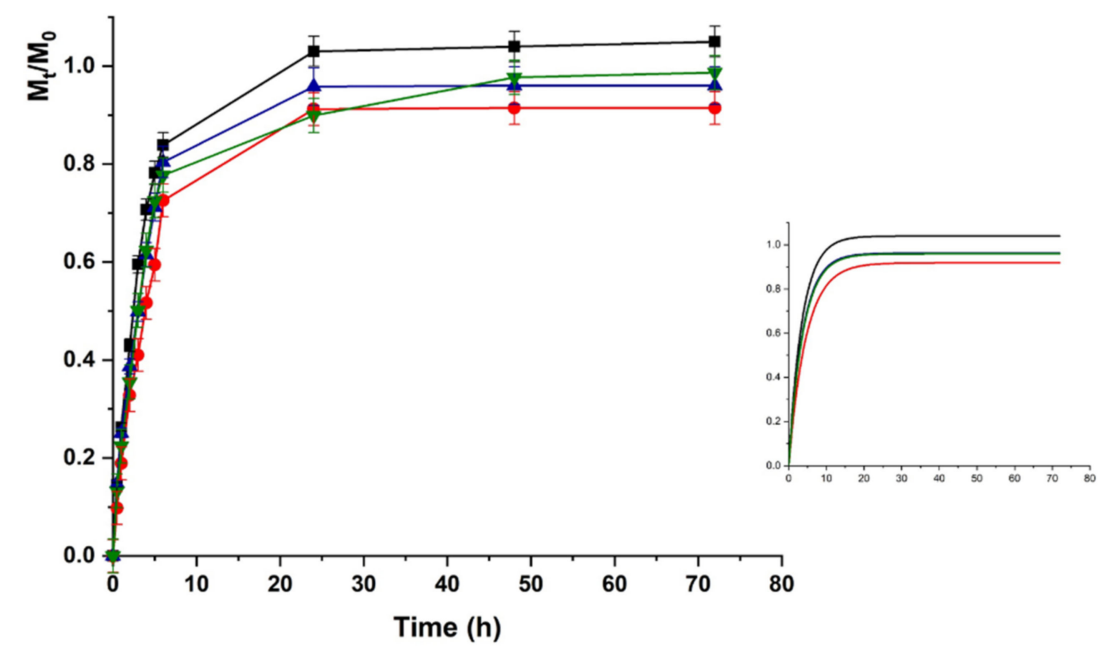

Figure 6. LZM release profiles from HAC at pH 7.4 and $(\mathbf{\square}) 0 ;(\bullet) 12 ;(\boldsymbol{\nabla}) 24$; and (ム) $48 \mathrm{~V}$. Inset: Fitting curve by Equation (3).

Table 2. Kinetic parameters for LZM release obtained by applying the kinetic models.

\begin{tabular}{|c|c|c|c|c|c|c|c|c|c|c|c|c|c|}
\hline \multirow[b]{2}{*}{ Sample } & \multirow[b]{2}{*}{$\mathrm{pH}$} & \multirow[b]{2}{*}{ Voltage } & \multicolumn{2}{|c|}{ Zero Order } & \multicolumn{2}{|c|}{ First Order } & \multicolumn{3}{|c|}{ Ritger-Peppas } & \multicolumn{4}{|c|}{ Peppas-Sahlin } \\
\hline & & & $\mathrm{K}_{0}$ & $\mathbf{R}^{2}$ & $K_{1}$ & $\mathbf{R}^{2}$ & $\mathbf{n}$ & $\mathbf{K}$ & $\mathbf{R}^{2}$ & $\mathbf{K}_{\mathbf{F}}$ & $\begin{array}{c}\mathrm{K}_{\mathrm{a}} \\
\left(10^{-2}\right)\end{array}$ & $\frac{K_{F}}{K_{a}}$ & $\mathbf{R}^{2}$ \\
\hline \multirow{4}{*}{ HAC } & \multirow{4}{*}{5.5} & 0 & 0.0178 & 0.8384 & 0.0780 & 0.9778 & 0.45 & 0.1590 & 0.9894 & 0.1633 & 0.43 & 38 & 0.9831 \\
\hline & & 12 & 0.0170 & 0.8301 & 0.0719 & 0.9490 & 0.43 & 0.1678 & 0.9906 & 0.1629 & 0.51 & 32 & 0.9949 \\
\hline & & 24 & 0.0167 & 0.8517 & 0.0621 & 0.9480 & 0.47 & 0.1358 & 0.9647 & 0.1417 & 0.21 & 67 & 0.9683 \\
\hline & & 48 & 0.0165 & 0.8655 & 0.0579 & 0.9434 & 0.49 & 0.1292 & 0.9670 & 0.1323 & 0.14 & 94 & 0.9724 \\
\hline \multirow{4}{*}{ HACG } & \multirow{4}{*}{5.5} & 0 & 0.0072 & 0.9490 & 0.0098 & 0.9640 & 0.67 & 0.0277 & 0.9808 & 0.0302 & 0.31 & 10 & 0.9744 \\
\hline & & 12 & 0.0155 & 0.8831 & 0.0458 & 0.9783 & 0.50 & 0.1117 & 0.9839 & 0.1175 & 0.04 & 293 & 0.9859 \\
\hline & & 24 & 0.0106 & 0.8664 & 0.0187 & 0.8646 & 0.48 & 0.0854 & 0.9854 & 0.0871 & 0.16 & 54 & 0.9902 \\
\hline & & 48 & 0.0108 & 0.8587 & 0.0196 & 0.8481 & 0.46 & 0.0924 & 0.9858 & 0.0921 & 0.17 & 54 & 0.9896 \\
\hline \multirow{4}{*}{ HAC } & \multirow{4}{*}{7.4} & 0 & 0.0202 & 0.5454 & 0.3006 & 0.9952 & 0.23 & 0.4349 & 0.7824 & 0.3785 & 3.10 & 12 & 0.9478 \\
\hline & & 12 & 0.0176 & 0.5958 & 0.1895 & 0.9783 & 0.27 & 0.3251 & 0.8145 & 0.2977 & 2.27 & 13 & 0.9555 \\
\hline & & 24 & 0.0186 & 0.5493 & 0.2495 & 0.9928 & 0.23 & 0.3950 & 0.7848 & 0.3456 & 2.82 & 12 & 0.9522 \\
\hline & & 48 & 0.0187 & 0.5702 & 0.2427 & 0.9896 & 0.38 & 0.3795 & 0.7999 & 0.3330 & 2.64 & 13 & 0.9378 \\
\hline \multirow{4}{*}{ HACG } & \multirow{4}{*}{7.4} & 0 & 0.0104 & 0.5154 & 0.3316 & 0.9825 & 0.20 & 0.2508 & 0.8266 & 0.2063 & 1.75 & 11 & 0.9474 \\
\hline & & 12 & 0.0186 & 0.3959 & 0.5843 & 0.9915 & 0.14 & 0.5839 & 0.5334 & 0.4509 & 4.25 & 10 & 0.8118 \\
\hline & & 24 & 0.0166 & 0.5205 & 0.2992 & 0.9901 & 0.22 & 0.3776 & 0.7383 & 0.3249 & 2.74 & 11 & 0.9313 \\
\hline & & 48 & 0.0168 & 0.4862 & 0.3653 & 0.9905 & 0.19 & 0.4241 & 0.7335 & 0.3502 & 3.06 & 11 & 0.9248 \\
\hline
\end{tabular}

The same trend was recorded for HACG, where a faster release was recorded at physiological vs. acidic $\mathrm{pH}$ (higher kinetic constants), although the maximum amount of release was around $50 \%$ in both cases (Figures 7 and 8 ). 


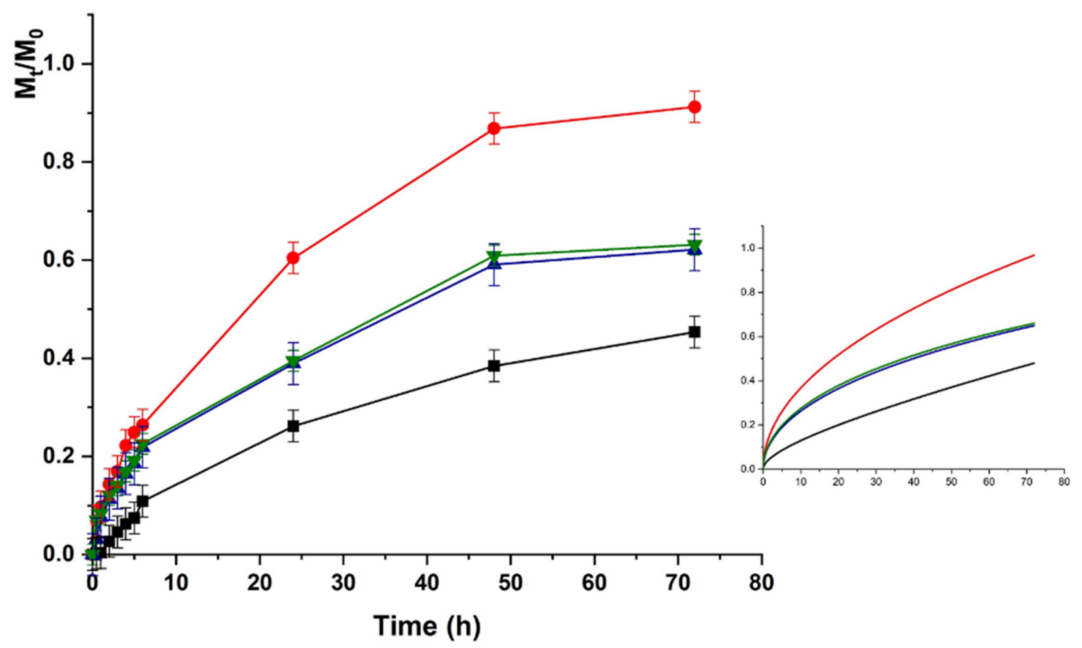

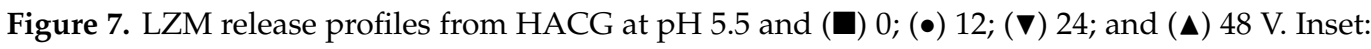
Fitting curve by Equation (5).

Here, the presence of GO affected the LZM to hydrogel interaction since GO is able to interact with the bioactive protein via both electrostatic $(\mathrm{COOH})$ and $\pi-\pi$ stacking interactions, thus, resulting in higher affinity at both $\mathrm{pH}$ conditions.

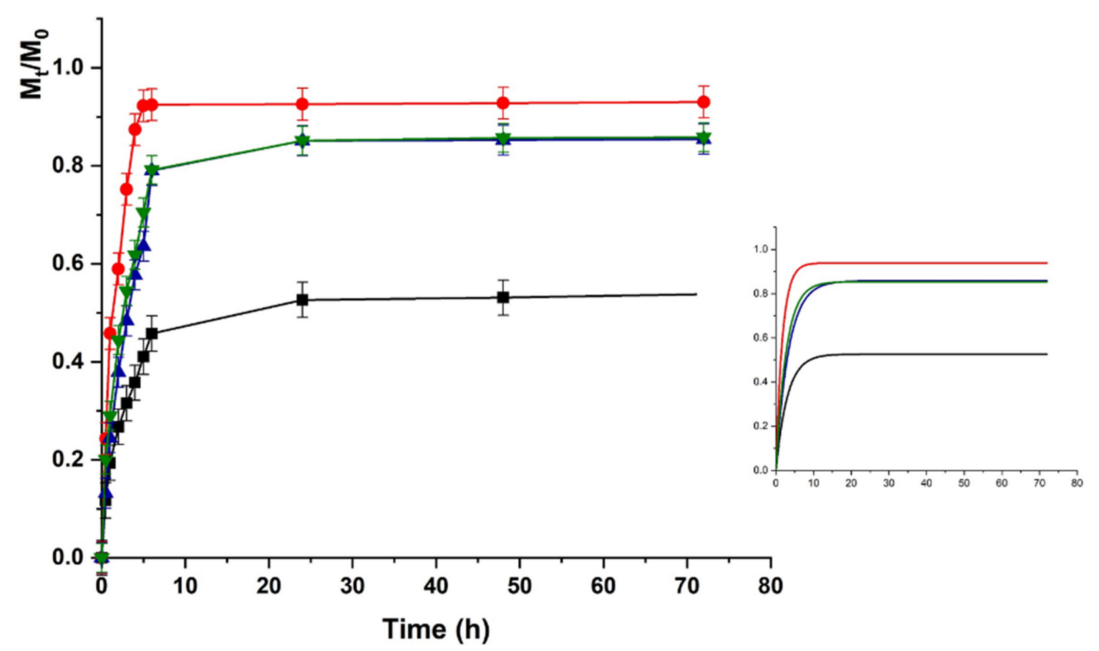

Figure 8. LZM release profiles from HACG at pH 7.4 and $(\boldsymbol{\square}) 0 ;(\bullet) 12 ;(\boldsymbol{\nabla}) 24$; and $(\boldsymbol{\Delta}) 48 \mathrm{~V}$. Inset: Fitting curve by Equation (3).

Further considerations can be done by considering the release upon application of an external electric field. As expected, no significant modification in the release amount and rate was recorded when HAC was used, due to the absence of any electro-conductive component in the polymer network. A different behavior was observed for the HACG hybrid hydrogel. The application of an electric field with different voltages resulted in a fine tuning of the delivery profiles, with the release at physiological $\mathrm{pH}$ being faster than that at acidic $\mathrm{pH}$ in all voltage conditions, due to the above-mentioned modulation of LZM to hydrogel interactions upon $\mathrm{pH}$ variation.

The differences in the release profiles at each selected voltage could be attributed to the modulation of both the swelling degree and the ionization state of the entire system (LZM + HACG) by the electrical stimulation. In detail, a significant increase in the release was recorded when $12 \mathrm{~V}$ was applied, as a consequence of the higher degree of swelling of the polymer network, promoting LZM diffusion to the surrounding environment. A further increase in the applied voltage $(24 \mathrm{~V})$, carried out to an enhanced ionization of $\mathrm{COOH}$ residues, allowed the formation of a higher number of negative charges suitable 
for interaction with LZM, and thus reduced the release rate/amount. A further increase in the voltage did not result in a significative modification of the release kinetics at both $\mathrm{pHs}$, probably because of the formation of an equilibrium state between the LZM-HACG interaction and the strong osmotic pressure formed across the network hindering the diffusion. Further confirmations of this hypothesis can be obtained by investigating the modification of $\mathrm{K}_{\mathrm{F}}$ and $\mathrm{K}_{\mathrm{a}}$ kinetic constants in Equation (5) (indicating the diffusional and anomalous contributions, respectively) upon application of an external voltage. In all cases, the Fickian diffusion is the predominant effect $\left(\mathrm{K}_{\mathrm{F}} / \mathrm{K}_{\mathrm{a}}>10\right)$, with the fast release at 12 vs. $0 \mathrm{~V}$ determining a significant increase in the $\mathrm{K}_{\mathrm{F}} / \mathrm{K}_{\mathrm{a}}$. When 24 and $48 \mathrm{~V}$ were applied, the insurgence of the osmotic stress contribution was highlighted by the simultaneous $\mathrm{K}_{\mathrm{F}}$ reduction and $\mathrm{K}_{\mathrm{a}}$ increase, with the $\mathrm{K}_{\mathrm{F}} / \mathrm{K}_{\mathrm{a}}$ value reduced by a half.

\subsection{Lysozyme Crystallization upon Oxidative Stress Condition}

The large wetting tendency of hydrophilic and porous surfaces of hydrogels was successfully employed in protein crystallization by virtue of their ability to reduce the activation energy to nucleation, thus, reducing the induction time and increasing the crystal growth rate $[60,61]$. This is importance in biomedicine, where significant research efforts have been expended for analyzing tertiary structures of proteins in order collect key information about the molecular mechanisms underlying cellular biological and pathological processes [62]. Nevertheless, chemical reactions occurring during crystallization can lead to poor reproducibility or even failure of the crystallization. Among others, the oxidization process in crystallization droplets is a key phenomenon to be considered, because of the formation of irreversible intermolecular disulfide bridges, oxidation films, and protein precipitates [24]. To address this issue, we explored the possibility of using the CF functionalities of HACG as a scavenging agent against the oxidative stress induced by $\mathrm{H}_{2} \mathrm{O}_{2}$ during LZM crystallization, preserving the protein tertiary structure.

To prove this hypothesis, the retainment of CF antioxidant potency upon conjugation to Alg and the further co-polymerization in the acrylate network were assessed by determining the available phenolic groups by the Folin-Ciocalteu tests [63], the Trolox (6-hydroxy-2,5,7,8-tetramethylchroman-2-carboxylic acid) equivalent antioxidant capacity (TEAC) [64], and the concentration needed for a 50\% decay $\left(\mathrm{IC}_{50}\right)$ of DPPH (1,1-diphenyl2-picrylhydrazyl) radical [65].

The determination of available phenolic groups allowed estimating a functionalization degree of $7.7 \mathrm{mg}$ CF per $\mathrm{g}$ of AlgCF. The TEAC value gives a clear indication about the number of radicals that can be quenched by a tested antioxidant compound; in our experimental conditions, TEAC values of 1.85 and 1.77 were obtained for free and conjugated CF (referred to the amount of conjugated CF as per Folin-Ciocalteu test), respectively, clearly demonstrating that the scavenging ability of CF was almost unchanged after insertion in the AlgCF side chains. The determination of $\mathrm{IC}_{50}$ values for DPPH radical $\left(0.85 \mathrm{mg} \mathrm{mL}^{-1}\right.$, corresponding to $6.7 \mu \mathrm{g} \mathrm{mL}^{-1} \mathrm{CF}$ equivalent concentration), close to that of free $\mathrm{CF}(6.1 \mu \mathrm{g}$ $\left.\mathrm{mL}^{-1}, p>0.05\right)$ was used as a further confirmation of this statement.

HACG was found to possess an available phenolic content of $0.63 \mathrm{mg} C F$ equivalent per g of dry hydrogel (suggesting an incorporation of $81.8 \mathrm{mg}$ AlgCF per g), a TEAC value of 1.48 (referred to the CF content as per the Folin-Ciocalteu test), and an $\mathrm{IC}_{50}$ value of $27.7 \mathrm{mg} \mathrm{mL}^{-1}$ in the DPPH assay $\left(17.45 \mu \mathrm{g} \mathrm{mL}^{-1} \mathrm{CF}\right.$ equivalent concentration).

Then, the functional hydrogel HACG was employed as substrate for LZM crystallization in standard conditions [66]. The conventional hanging drop crystallization technique was used to investigate the best conditions for obtaining good results in terms of the quality of the lysozyme crystals. In general, in a crystallization process the best results in terms of crystal quality are obtained when the crystals displayed on the drop at the end of the process are few and large. However, several parameters could influence the steps of crystal nucleation and growth. Nucleation starts when the protein solution reaches an optimal level of oversaturation. In an ideal condition, key parameters related to the solution such as $\mathrm{pH}$, temperature, and precipitating agents, lead the protein solution to the narrow area 
of oversaturation, at which the protein can undergo a spontaneous nucleation. When the crystalline nuclei are formed, and therefore the level of over-saturation is reduced, the metastable zone is reached, where the growth of the crystal is favored [67].

As a general rule, an oversaturation condition is favored by adding suitable precipitating agents to the protein solution, such as PEG, organic solvents, or even inorganic salts such as sodium chloride. These contribute to the achievement of oversaturation in the solution by varying the chemical-physical characteristics (temperature, ionic strength, and $\mathrm{pH}$ ). In detail, inorganic salts serve this purpose by influencing the ionic strength of the protein solution.

In the case of the crystallization process performed in vapor phase, the polymeric hydrogel film, used as support by virtue of its porosity, promotes the establishment of a balance between the protein drop and the stripping solution present in the well, through the solvent evaporation from the drop to the stripping solution. Under these conditions, the oversaturation needed for nucleation is reached more easily. The best conditions, among those analyzed in this study, were a lysozyme protein solution concentration of $10 \mathrm{mg}$ $\mathrm{mL}^{-1}$ in sodium acetate buffer $0.1 \mathrm{M}, \mathrm{pH} 4.6$, and $7 \%$ w/v precipitating agent $(\mathrm{NaCl})$ diluted in the same buffer acetate (both in the drop and in the well).

The formation of LZM crystals on the surface of either HAG or HACG is shown in Figure 9, confirming that the CF residues did not interfere with the process.

In the presence of $\mathrm{H}_{2} \mathrm{O}_{2}$, the induced stress caused the crystallization process to fail when HAG was used as a support, obtaining small powder structures (Figure 10a-c).

Interestingly, when HACG was used as a support, the radical scavenging ability of $\mathrm{CF}$ residues counteracted the oxidizing activity of $\mathrm{H}_{2} \mathrm{O}_{2}$, resulting in the formation of well-defined LZM crystals (Figure 10d-f).

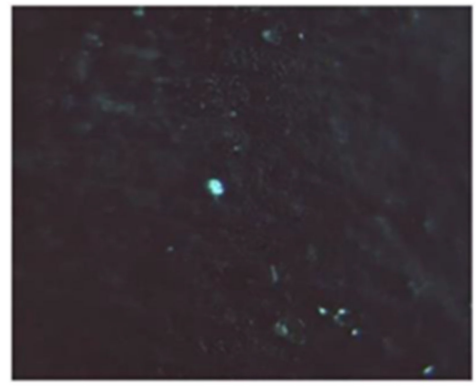

(a)

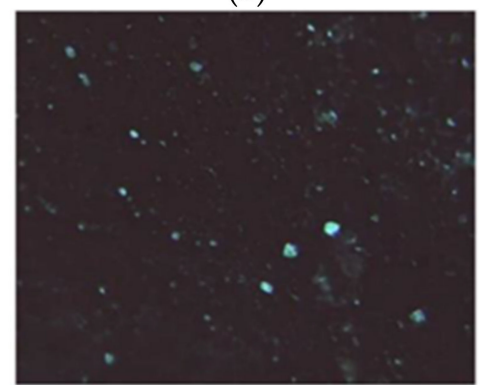

(d)

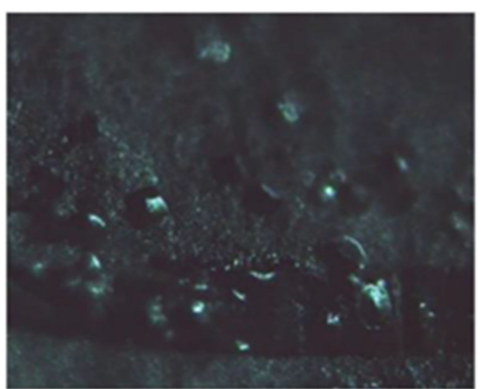

(b)

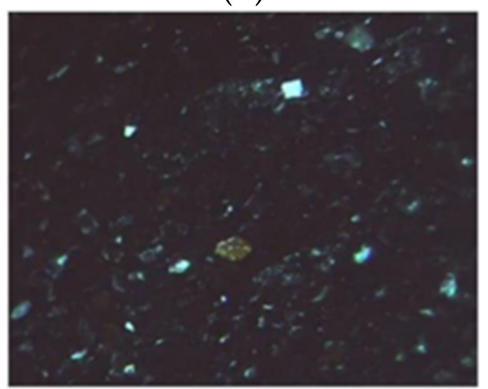

(e)

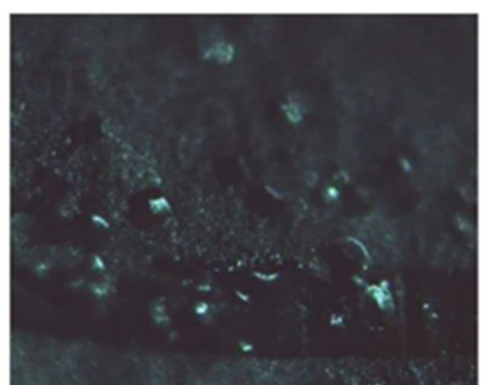

(c)

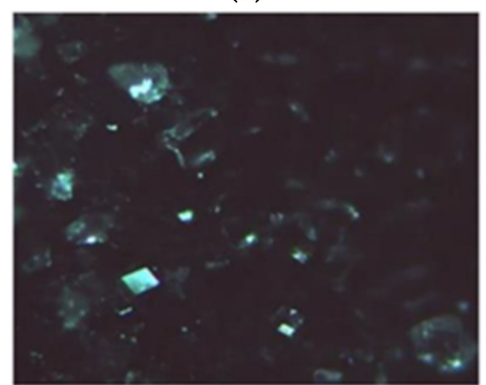

(f)

Figure 9. LZM crystals. (a-c) Observed on HAG; (d-f) Observed on HACG, after (a,d) 24, (b,e) 48, and (c,f) 72 h. 


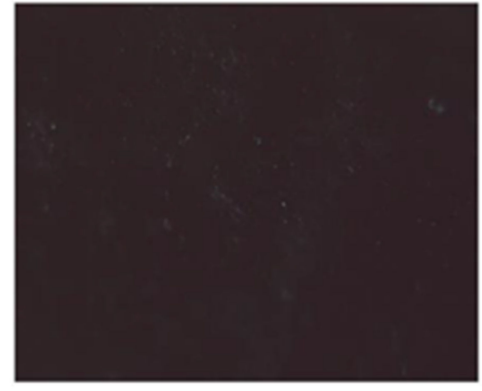

(a)

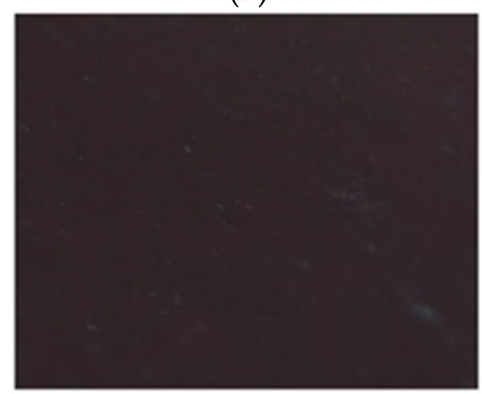

(d)

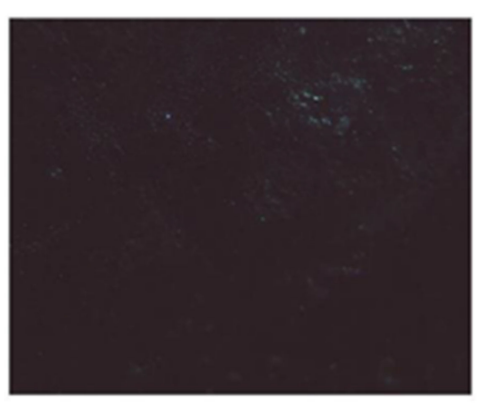

(b)

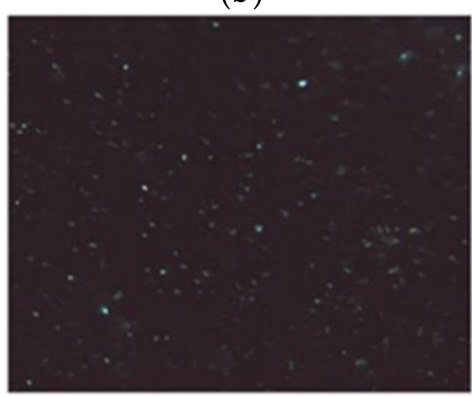

(e)

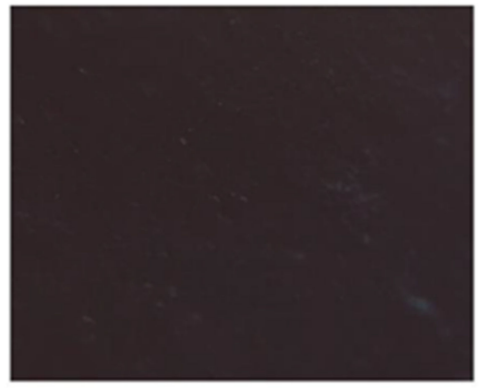

(c)

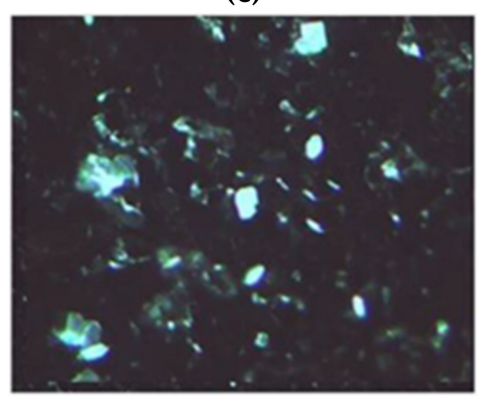

(f)

Figure 10. LZM crystals. (a-c) Observed on HAG; (d-f) Observed on HACG, after (a,d) 24, (b,e) 48 , and (c,f) $72 \mathrm{~h}$ in the presence of $\mathrm{H}_{2} \mathrm{O}_{2}$.

Our preliminary results can be considered to be proof of the potential applicability of HACG as functional material for LZM crystallization, with further experiments aimed to evaluate the applicability for crystallization of more complex oxidizable proteins.

\section{Materials and Methods}

\subsection{Synthesis of Alginate-Caffeic Acid Conjugate}

AlgCF was synthesized by means of heterogeneous catalysis involving the use of a previously developed immobilized laccase as solid biocatalyst [43]. Briefly, $100 \mathrm{mg}$ Alg and $10 \mathrm{mg} \mathrm{CF}$ were dissolved in $3.5 \mathrm{~mL} \mathrm{H}_{2} \mathrm{O}$ containing $5 \%$ DMSO, and, after the addition of $250 \mathrm{mg}$ biocatalyst $(11.5 \mathrm{U})$, reacted at $37^{\circ} \mathrm{C}$ under $70 \mathrm{rpm}$. After $12 \mathrm{~h}$, the conjugate was purified by dialysis in 6-27/32" dialysis tubes, MWCO 12,000-14,000 Da (Medicell International LTD, Liverpool, UK) against DMSO $/ \mathrm{H}_{2} \mathrm{O}$ mixture solution (5\%) until complete removal of unreacted $\mathrm{CF}$ in the washing media. Then, DMSO was removed by dialysis against water, and the solution was dried with a freeze drier (Micro Modulyo, Edwards Lifesciences, Irvine, CA, USA) to afford a vaporous solid. The presence of CF in the washing media was analyzed by high-pressure liquid chromatography (HPLC) in the following conditions: Jasco PU-2089 Plus liquid chromatography equipped with a Rheodyne $7725 \mathrm{i}$ injector ( $20 \mu \mathrm{L}$ loop), a Tracer Excel 120 ODS-A column particle size $5 \mu \mathrm{m}$, $15 \times 0.4 \mathrm{~cm}$ (Barcelona, Spain), a mobile phase consisting of acetonitrile-water containing $0.1 \%$ phosphoric acid (70:30) running at a flow rate of $1.5 \mathrm{~mL} \mathrm{~min}^{-1}$, a Jasco UV-2075 HPLC detector operating at $330 \mathrm{~nm}$, and a Jasco-Borwin integrator (Jasco Europe S.R.L., Milan, Italy) [68].

All chemicals were from Merck/Sigma Aldrich, Darmstadt, Germany.

\subsection{Synthesis of Hybrid Hydrogel}

Hybrid hydrogels were prepared via a previously developed polymerization procedure [51] consisting of preliminary dispersion of $5.0 \mathrm{mg}$ GO in $3.5 \mathrm{~mL}$ water containing $50 \mathrm{mg} \mathrm{AlgCF}$ water solution by a cup-horn high intensity ultrasonic homogenizer (SONOPULS) with a cylindrical tip (amplitude 70\%, time $30 \mathrm{~min}$ ). Then, $184 \mathrm{mg}$ HEA and $196 \mathrm{mg}$ PEGDMA were added, and the solution was purged with gaseous nitrogen for $20 \mathrm{~min}$. After adding ammonium persulfate $(10 \% \mathrm{w} / \mathrm{w})$, the polymerization mixture was 
allowed to react at $40{ }^{\circ} \mathrm{C}$ after placement between two $5.0 \times 5.0 \mathrm{~cm}^{2}$ glass plates, separated with a Teflon spacer $(0.6 \mathrm{~mm})$ and brought together by binder clips. The obtained hybrid hydrogels were extensively washed with water to remove unreacted species, and then dried overnight under vacuum at $40{ }^{\circ} \mathrm{C}$. Control hydrogels were prepared with the same procedure without the insertion of GO (HAC) or replacing AlgCF conjugate with native Alg (HAG).

All chemicals were from Merck/Sigma Aldrich, Darmstadt, Germany.

\subsection{Characterization Procedures}

\subsubsection{Instruments}

${ }^{1} \mathrm{H}-\mathrm{NMR}$ spectra $\left(300 \mathrm{MHz}, \mathrm{D}_{2} \mathrm{O}\right.$ ) were recorded using a Bruker Avance 300 (Bruker Italy, Milan, Italy).

Calorimetric analyses were carried out using a DSC200 PC differential scanning calorimeter (Netzsch, Selb, Germany). Following a standard procedure, about $5.0 \mathrm{mg}$ of dried sample was placed in an aluminum pan, and then sealed tightly by an aluminum lid. The thermal analyses were performed from 60 to $300{ }^{\circ} \mathrm{C}$ under a dry nitrogen atmosphere with a flow rate of $25 \mathrm{~mL} \mathrm{~min}^{-1}$ and heating rate of $5^{\circ} \mathrm{C} \mathrm{min}-1$.

Freeze-dried grounded samples were deposited onto self-adhesive, conducting carbon tape (Plano $\mathrm{GmbH}$, Wetzlar, Germany) and scanning electron microscope images were acquired using a NOVA NanoSEM $200(0-30 \mathrm{kV})$ (Thermo Fisher Scientific, Hillsboro, OR, USA).

Static light scattering measurements (Zetasizer Nano ZS instrument, Malvern Panalytical, Malvern, UK) were performed on $\mathrm{Alg}$ and $\mathrm{AlgCF}$ water solutions with a concentration between 0.1 and $5.0 \mathrm{mg} \mathrm{mL}^{-1}$ in order to determine the average molecular weight [69]. All the solutions were filtered using a $0.22 \mu \mathrm{m}$ filter (Millex ${ }^{\circledR}$-GV syringe-driven filter unit, Merck/Sigma Aldrich, Darmstadt, Germany), and then placed in quartz cuvettes. The light intensity and its time autocorrelation function were measured at $173^{\circ}$ scattering angle after 2 min of equilibration at $25^{\circ} \mathrm{C}$ using automatic time settings.

The Debye plots were generated by using Debye's light scattering Equation (6):

$$
\frac{K C}{R_{\theta}}=\frac{1}{M_{W}}+2 B_{22} C
$$

where $R_{\theta}$ is the excess Rayleigh ratio of the polymer in a solution with a polymer concentration $C$ and $\mathrm{M}_{\mathrm{W}}$ is the average molecular weight. $\mathrm{K}$ is the optical constant and is defined as reported in the following Equation (7):

$$
K=\frac{4 \pi^{2} n^{2}}{N_{A} \lambda^{4}}\left(\frac{d n}{d c}\right)^{2}
$$

where $\mathrm{n}$ is the solvent refractive index, $\mathrm{dn} / \mathrm{dc}$ is the refractive index increment, $\lambda$ is the wavelength of the incident light, and $\mathrm{N}_{\mathrm{A}}$ is the Avogadro's number. The average molecular weight was obtained from the inverse of the intercept of the linear Debye plot of $\mathrm{KC} / R_{\theta}$ versus the polymer concentration C.

\subsubsection{Antioxidant Tests}

The amount of total phenolic equivalents, expressed as CF equivalent per $\mathrm{g}$ of sample was determined using Folin-Ciocalteu assay, as reported in [63], using the calibration curve of the free antioxidant. The TEAC values were determined according to a previously reported protocol with slight modifications [64]. In separate experiments, AlgCF and swollen HACG at a CF equivalent concentration of $2.0 \mu \mathrm{g} \mathrm{mL}^{-1}$ were added to 2,2'-azinobis(3ethylbenzothiazoline-6-sulphonic acid) (ABTS) solution in the $0-1.2310^{-4} \mathrm{~mol} \mathrm{~L}^{-1}$ con- 
centration range and incubated at $37^{\circ} \mathrm{C}$ for $6 \mathrm{~min}$ in the dark. Then, the absorbance was measured at $734 \mathrm{~nm}$ and the following Equation (8) was used to calculate TEAC:

$$
T E A C=\frac{1}{1.9[C F]}
$$

where 1.9 is the number of molecules that can be scavenged per mol trolox, [CF] is the $\mathrm{CF}$ equivalent concentration $\left(\mathrm{mol} \mathrm{L}^{-1}\right)$ in the sample. The maximal amount of ABTS scavenged by the $\mathrm{CF}$ at the tested concentration, $\mathrm{C}$, was calculated by plotting the reduction of ABTS concentration against its initial concentration according to the following Equation (9):

$$
y=C\left(1-e^{-b x}\right)
$$

where $\mathrm{x}$ and $\mathrm{y}$ are the initial ABTS concentration and the reduction in ABTS concentration, respectively.

Radical scavenging properties were evaluated measuring the inhibition (\%) of the stable 2,2'-diphenyl-1-picrylhydrazyl radical (DPPH) radical by AlgCF (from 0.25 to $1.50 \mathrm{mg} \mathrm{mL}^{-1}$ ) and swollen HACG (from 15.0 to $30.0 \mathrm{mg} \mathrm{mL}^{-1}$ ), according to the literature protocol and the following Equation (10) [65]:

$$
\text { Inhibition }(\%)=\frac{A_{0}-A_{1}}{A_{0}} \times 100
$$

where $A_{0}$ and $A_{1}$ are the absorbances of DPPH solution in the absence or presence of polymer samples, respectively.

The water affinity of HAC and HACG was investigated in PBS (pH 7.4) and sodium acetate buffer ( $\mathrm{pH} 5.5$ ) under different voltage conditions (0, 12, 24, and $48 \mathrm{~V}$ ). Briefly, $1.0 \mathrm{~cm}^{2}$ specimens were cut from each sample, weighed, and immersed into the swelling medium at $37^{\circ} \mathrm{C}$. Excess water was removed after $24 \mathrm{~h}$, and samples blotted with a tissue to remove surface moisture and weighed. The water content percentage (WR) was expressed by the following Equation (11):

$$
W R(\%)=\frac{W_{s}-W_{d}}{W_{d}} \times 100
$$

where $W_{s}$ and $W_{d}$ are the sample weights in their swollen and dry state.

All chemicals were from Merck/Sigma Aldrich, Darmstadt, Germany.

\subsubsection{Cytotoxicity Studies}

The cytotoxic effects of HACG were assessed on human fibroblast lung cells MRC-5 (ATCC CCL-171). Briefly, cells were cultured in Dulbecco's modified Eagle's medium (DMEM) supplemented with $10 \% \mathrm{FBS}$ and $1 \%$ L-glutamate, grown as a monolayer at $37^{\circ} \mathrm{C}$ in $5 \% \mathrm{CO}_{2}$, and seeded into 96 -well plates (100 mL per well) at a predetermined density $(20,000$ cells / well) to achieve $90 \%$ confluency by the endpoint of the assay.

For the cytotoxicity determination, HACG was pulverized, and incubated with MRC-5 cells after being suspended in DMEM + FCS 10\% (0.1-1.0 mg mL ${ }^{-1}$ range of concentration). After $72 \mathrm{~h}$ of incubation, the media containing treatment was replaced with $10 \%$ AlamarBlue in fresh media. The metabolic activity was detected by spectrophotometric analysis by assessing the absorbance of AlamarBlue ${ }^{\circledR}$ (difference between $570 \mathrm{~nm}$ and $595 \mathrm{~nm}$ ) using a Bio Rad multiplate reader. Cell viability was determined and expressed as the percentage of viability of untreated control cells.

All chemicals were from Merck/Sigma Aldrich, Darmstadt, Germany.

\subsection{Lysozyme Loading and In Vitro Release Studies}

LZM was loaded into hybrid hydrogels at $6.0 \%$ (by weight) by soaking $50 \mathrm{mg}$ of dried samples (HAC or HACG) with $3.5 \mathrm{~mL} \mathrm{LZM} \mathrm{solution,} \mathrm{in} \mathrm{water}\left(1.0 \mathrm{mg} \mathrm{mL}^{-1}\right)$ for 3 days, 
and then samples were dried to a constant weight at reduced pressure in the presence of $\mathrm{P}_{2} \mathrm{O}_{5}$.

The in vitro LZM release was investigated by dissolution method with alternate shaking both in the absence and in the presence of an external electric voltage $(12,24$, and $48 \mathrm{~V}$ ). In separate experiments, specimens of $\sim 1 \mathrm{~cm}^{2}$ of loaded hydrogels were weighted and immersed in flasks containing $10 \mathrm{~mL}$ PBS ( $\mathrm{pH} 7.4)$ and sodium acetate buffer $(\mathrm{pH}$ 5.5) solutions at $37.0 \pm 0.1{ }^{\circ} \mathrm{C}$ in a water bath. At suitable time intervals, $1.0 \mathrm{~mL}$ release medium was withdrawn and replaced with fresh medium to ensure sink conditions during the experiment. After filtration (Iso-DiscTM Filters PTFE 25-4 $25 \mathrm{~mm} \times 0.45 \mu \mathrm{m}$, Supelco/Merck, Darmstadt, Germany), released LZM was measured by UV-Vis analysis on an Evolution 201 spectrophotometer (ThermoFisher Scientific, Hillsboro, OR, USA) operating with $1.0 \mathrm{~cm}$ quartz cells at $280 \mathrm{~nm}$ [70].

All chemicals were from Merck/Sigma Aldrich, Darmstadt, Germany.

\subsection{Lysozyme Crystallization}

The crystallization tests were performed by conventional hanging drop vapor diffusion method using the prepared thin films of hydrogel as crystallization supports. Lysozyme was dissolved in sodium acetate buffer $(0.1 \mathrm{M}, \mathrm{pH} 4.6)$ at the initial concentration of $10 \mathrm{mg} \mathrm{mL}^{-1}$. The precipitant and stripping solutions were composed of sodium chloride, $\mathrm{NaCl}(7.0 \mathrm{wt} \%$ ), dissolved in the same buffer. A drop of protein solution $(5 \mu \mathrm{L})$, pipetted on the surface of the hydrogel membrane and added with an equal volume of precipitant solution, was left equilibrating with $6 \mathrm{~mL}$ of stripping solution in the well. The final crystallization solution, after mixing the protein and precipitant solutions, was $5 \mathrm{mg} \mathrm{mL}^{-1}$.

To assure the result reproducibility, 5 replica experiments for each tested condition were carried out. Then, the crystallization system was incubated at $20 \pm 0.1{ }^{\circ} \mathrm{C}$ before optical microscopy inspection of the droplets after time intervals of 24,48 , and $72 \mathrm{~h}$. Protein crystals were observed under an optical microscope (Axiovert 25, Zeiss, Oberkochen, Germany) equipped with a video camera. The same experimental conditions were used when $\mathrm{H}_{2} \mathrm{O}_{2}(15 \% \mathrm{w} / \mathrm{v})$ was added to the hanged drop and the reservoir solution.

\section{Conclusions}

We provided experimental evidence that a novel multifunctional hybrid hydrogel is an effective platform to either provide the electro-responsive release of biologically active molecules such as LZM or facilitate its crystallization under oxidative stress. This ability arises from the combination of the peculiar features of the network component; GO was responsible for the electro-conductivity and high affinity to LZM, while the AlgCF conjugate was the functional element with antioxidant properties.

The synthetic strategy consisted of two steps. First, AlgCF was synthesized by enzyme catalysis, and then inserted into the acrylate polymer network together with GO showing high biocompatibility and water affinity. The evaluation of the LSM release profile highlighted a $\mathrm{pH}$ - and electro-responsivity reliance, because of the variation of the ionization degree of carboxyl functionalities on AlgCF and GO, and the insurgence of an osmotic pressure within the swollen hydrogels upon application of an electric field.

Finally, the LZM crystallization experiments conducted in the presence of $\mathrm{H}_{2} \mathrm{O}_{2}$ proved the suitability of hybrid hydrogel to counteract protein denaturation, thus, facilitating the formation of well-defined crystals under oxidative conditions.

Overall, our results have shown the potential to perform subsequent studies for the development of further experimental protocols to evaluate the applicability of the proposed hydrogel system as a support for the delivery or the investigation of the three-dimensional (3D) structure of biologically relevant proteins.

Author Contributions: Conceptualization, G.C. and F.P.N.; data curation, A.L., F.I., G.D.F. and F.P.N.; formal analysis, G.C., A.L. and G.D.F.; investigation, E.P., M.C. and O.V.; methodology, G.C., O.V. and F.P.N.; resources, F.P.N.; supervision, F.I. and F.P.N.; validation, G.D.F. and F.P.N.; visualization, 
M.C. and F.I.; writing—original draft, G.C.; writing—review and editing, O.V., A.L. and F.P.N. All authors have read and agreed to the published version of the manuscript.

Funding: This research received no external funding.

Institutional Review Board Statement: Not Applicable.

Informed Consent Statement: Not Applicable.

Data Availability Statement: Not Applicable.

Conflicts of Interest: The authors declare no conflict of interest.

Sample Availability: Samples of the compounds are available from the authors.

\section{References}

1. Yi, J.; Choe, G.; Park, J.; Lee, J.Y. Graphene oxide-incorporated hydrogels for biomedical applications. Polym. J. 2020, 52, 823-837. [CrossRef]

2. Buwalda, S.J.; Boere, K.W.M.; Dijkstra, P.J.; Feijen, J.; Vermonden, T.; Hennink, W.E. Hydrogels in a historical perspective: From simple networks to smart materials. J. Control. Release 2014, 190, 254-273. [CrossRef]

3. Di Profio, G.; Polino, M.; Nicoletta, F.P.; Belviso, B.D.; Caliandro, R.; Fontananova, E.; De Filpo, G.; Curcio, E.; Drioli, E. Tailored Hydrogel Membranes for Efficient Protein Crystallization. Adv. Funct. Mater. 2014, 24, 1582-1590. [CrossRef]

4. Tibbitt, M.W.; Dahlman, J.E.; Langer, R. Emerging Frontiers in Drug Delivery. J. Am. Chem. Soc. 2016, 138, 704-717. [CrossRef] [PubMed]

5. Kost, J.; Langer, R. Responsive polymeric delivery systems. Adv. Drug. Deliver. Rev. 2012, 64, 327-341. [CrossRef]

6. Wang, L.; He, G.H.; Ruan, X.H.; Zhang, D.S.; Xiao, W.; Li, X.C.; Wu, X.M.; Jiang, X.B. Tailored Robust Hydrogel Composite Membranes for Continuous Protein Crystallization with Ultrahigh Morphology Selectivity. ACS Appl. Mater. Interfaces 2018, 10, 26653-26661. [CrossRef] [PubMed]

7. Salehi, S.M.; Manju, A.C.; Belviso, B.D.; Portugal, C.A.M.; Coelhoso, I.M.; Mirabelli, V.; Fontananova, E.; Caliandro, R.; Crespo, J.G.; Curcio, E.; et al. Hydrogel Composite Membranes Incorporating Iron Oxide Nanoparticles as Topographical Designers for Controlled Heteronucleation of Proteins. Cryst. Growth Des. 2018, 18, 3317-3327. [CrossRef]

8. Fernandez-Leiro, R.; Scheres, S.H.W. Unravelling biological macromolecules with cryo-electron microscopy. Nature 2016, 537, 339-346. [CrossRef]

9. Gu, H.B.; Liu, C.T.; Zhu, J.H.; Gu, J.W.; Wujcik, E.K.; Shao, L.; Wang, N.; Wei, H.G.; Scaffaro, R.; Zhang, J.X.; et al. Introducing advanced composites and hybrid materials. Adv. Compos. Hybrid Mater. 2018, 1, 1-5. [CrossRef]

10. Wegst, U.G.K.; Bai, H.; Saiz, E.; Tomsia, A.P.; Ritchie, R.O. Bioinspired structural materials. Nat. Mater. 2015, 14, 23-36. [CrossRef]

11. Jia, X.Q.; Kiick, K.L. Hybrid Multicomponent Hydrogels for Tissue Engineering. Macromol. Biosci. 2009, 9, 140-156. [CrossRef] [PubMed]

12. Prusty, K.; Swain, S.K. Polypropylene oxide/polyethylene oxide-cellulose hybrid nanocomposite hydrogels as drug delivery vehicle. J. Appl. Polym. Sci. 2021, 138, 49921. [CrossRef]

13. Hinderer, S.; Layland, S.L.; Schenke-Layland, K. ECM and ECM-like materials-Biomaterials for applications in regenerative medicine and cancer therapy. Adv. Drug Deliv. Rev. 2016, 97, 260-269. [CrossRef]

14. Iglesias, D.; Bosi, S.; Melchionna, M.; Da Ros, T.; Marchesan, S. The Glitter of Carbon Nanostructures in Hybrid/Composite Hydrogels for Medicinal Use. Curr. Top. Med. Chem. 2016, 16, 1976-1989. [CrossRef] [PubMed]

15. Gooneh-Farahani, S.; Naimi-Jamal, M.R.; Naghib, S.M. Stimuli-responsive graphene-incorporated multifunctional chitosan for drug delivery applications: A review. Expert Opin. Drug Deliv. 2019, 16, 79-99. [CrossRef] [PubMed]

16. Zhang, Q.; Deng, H.; Li, H.J.; Song, K.Y.; Zeng, C.; Rong, L. Preparation of Graphene Oxide-Based Supramolecular Hybrid Nanohydrogel Through Host-Guest Interaction and Its Application in Drug Delivery. J. Biomed. Nanotechnol. 2018, 14, $2056-2065$. [CrossRef] [PubMed]

17. Gonzalez-Dominguez, J.M.; Martin, C.; Dura, O.J.; Merino, S.; Vazquez, E. Smart Hybrid Graphene Hydrogels: A Study of the Different Responses to Mechanical Stretching Stimulus. ACS Appl. Mater. Interfaces 2018, 10, 1987-1995. [CrossRef]

18. Ganguly, S.; Ray, D.; Das, P.; Maity, P.P.; Mondal, S.; Aswal, V.K.; Dhara, S.; Das, N.C. Mechanically robust dual responsive water dispersible-graphene based conductive elastomeric hydrogel for tunable pulsatile drug release. Ultrason. Sonochem. 2018, 42, 212-227. [CrossRef]

19. Cirillo, G.; Curcio, M.; Spizzirri, U.G.; Vittorio, O.; Tucci, P.; Picci, N.; Iemma, F.; Hampel, S.; Nicoletta, F.P. Carbon nanotubes hybrid hydrogels for electrically tunable release of Curcumin. Eur. Polym. J. 2017, 90, 1-12. [CrossRef]

20. Kim, B.; Kang, B.; Vales, T.P.; Yang, S.K.; Lee, J.; Kim, H.J. Polyphenol-Functionalized Hydrogels Using an Interpenetrating Chitosan Network and Investigation of Their Antioxidant Activity. Macromol. Res. 2018, 26, 35-39. [CrossRef]

21. Feng, Y.; Xiao, K.; He, Y.; Du, B.; Hong, J.; Yin, H.; Lu, D.; Luo, F.; Li, Z.; Li, J.; et al. Tough and biodegradable polyurethanecurcumin composited hydrogel with antioxidant, antibacterial and antitumor properties. Mater. Sci. Eng. C 2021, 121, 111820. [CrossRef] [PubMed] 
22. Witzler, M.; Alzagameem, A.; Bergs, M.; El Khaldi-Hansen, B.; Klein, S.E.; Hielscher, D.; Kamm, B.; Kreyenschmidt, J.; Tobiasch, E.; Schulze, M. Lignin-Derived Biomaterials for Drug Release and Tissue Engineering. Molecules 2018, 23, 1885. [CrossRef]

23. Di Luca, M.; Curcio, M.; Valli, E.; Cirillo, G.; Voli, F.; Butini, M.E.; Farfalla, A.; Pantuso, E.; Leggio, A.; Nicoletta, F.P.; et al. Combining antioxidant hydrogels with self-assembled microparticles for multifunctional wound dressings. J. Mater. Chem. $B$ 2019, 7, 4361-4370. [CrossRef]

24. Senda, M.; Senda, T. Anaerobic crystallization of proteins. Biophys. Rev. 2018, 10, 183-189. [CrossRef] [PubMed]

25. Senda, M.; Kishigami, S.; Kimura, S.; Senda, T. Crystallization and preliminary X-ray analysis of the reduced Rieske-type [2Fe-2S] ferredoxin derived from Pseudomonas sp. strain KKS102. Acta Cryst. Sect. F Struct. Biol. Cryst. Commun. 2007, 63, 311-314. [CrossRef] [PubMed]

26. Liu, Y.; Li, Y.F.; Keskin, D.; Shi, L.Q. Poly(beta-Amino Esters): Synthesis, Formulations, and Their Biomedical Applications. Adv. Health Mater. 2019, 8, 1801359. [CrossRef]

27. Adlington, K.; Nguyen, N.T.; Eaves, E.; Yang, J.; Chang, C.Y.; Li, J.N.; Gower, A.L.; Stimpson, A.; Anderson, D.G.; Langer, R.; et al. Application of Targeted Molecular and Material Property Optimization to Bacterial Attachment-Resistant (Meth)acrylate Polymers. Biomacromolecules 2016, 17, 2830-2838. [CrossRef]

28. Das, D.; Pham, H.T.T.; Lee, S.; Noh, I. Fabrication of alginate-based stimuli-responsive, non-cytotoxic, terpolymric semi-IPN hydrogel as a carrier for controlled release of bovine albumin serum and 5-amino salicylic acid. Mat. Sci. Eng. C Mater. 2019, 98, 42-53. [CrossRef]

29. Chen, Y.W.; Lu, C.H.; Shen, M.H.; Lin, S.Y.; Chen, C.H.; Chuang, C.K.; Ho, C.C. In vitro evaluation of the hyaluronic acid/alginate composite powder for topical haemostasis and wound healing. Int. Wound J. 2020, 17, 394-404. [CrossRef]

30. Zhang, M.; Zhao, X. Alginate hydrogel dressings for advanced wound management. Int. J. Biol. Macromol. 2020, 162, 1414-1428. [CrossRef]

31. Puscaselu, R.G.; Lobiuc, A.; Dimian, M.; Covasa, M. Alginate: From Food Industry to Biomedical Applications and Management of Metabolic Disorders. Polymers 2020, 12, 2417. [CrossRef]

32. Sugahara, M. A Technique for High-Throughput Protein Crystallization in Ionically Cross-Linked Polysaccharide Gel Beads for X-Ray Diffraction Experiments. PLoS ONE 2014, 9, 95017. [CrossRef]

33. Willaert, R.; Zegers, I.; Wyns, L.; Sleutel, M. Protein crystallization in hydrogel beads. Acta Crystallogr. Sect. D Struct. Biol. 2005, 61, 1280-1288. [CrossRef] [PubMed]

34. Espindola, K.M.M.; Ferreira, R.G.; Narvaez, L.E.M.; Rosario, A.C.R.S.; da Silva, A.H.M.; Silva, A.G.B.; Vieira, A.P.O.; Monteiro, M.C. Chemical and Pharmacological Aspects of Caffeic Acid and Its Activity in Hepatocarcinoma. Front. Oncol. $2019,9,541$. [CrossRef]

35. Raja, S.T.K.; Thiruselvi, T.; Aravindhan, R.; Mandal, A.B.; Gnanamani, A. In vitro and in vivo assessments of a 3-(3,4dihydroxyphenyl)-2-propenoic acid bioconjugated gelatin-based injectable hydrogel for biomedical applications. J. Mater. Chem. B 2015, 3, 1230-1244. [CrossRef]

36. Goenka, S.; Sant, V.; Sant, S. Graphene-based nanomaterials for drug delivery and tissue engineering. J. Control. Release 2014, 173, 75-88. [CrossRef] [PubMed]

37. Liu, J.Q.; Cui, L.; Losic, D. Graphene and graphene oxide as new nanocarriers for drug delivery applications. Acta Biomater. 2013, 9, 9243-9257. [CrossRef] [PubMed]

38. Kuila, T.; Bose, S.; Mishra, A.K.; Khanra, P.; Kim, N.H.; Lee, J.H. Chemical functionalization of graphene and its applications. Prog. Mater. Sci. 2012, 57, 1061-1105. [CrossRef]

39. Yu, X.W.; Cheng, H.H.; Zhang, M.; Zhao, Y.; Qu, L.T.; Shi, G.Q. Graphene-based smart materials. Nat. Rev. Mater. 2017, 2, 17046. [CrossRef]

40. Curcio, M.; Farfalla, A.; Saletta, F.; Valli, E.; Pantuso, E.; Nicoletta, F.P.; Iemma, F.; Vittorio, O.; Cirillo, G. Functionalized Carbon Nanostructures Versus Drug Resistance: Promising Scenarios in Cancer Treatment. Molecules 2020, 25, 2102. [CrossRef]

41. Vittorio, O.; Curcio, M.; Cojoc, M.; Goya, G.F.; Hampel, S.; Iemma, F.; Dubrovska, A.; Cirillo, G. Polyphenols delivery by polymeric materials: Challenges in cancer treatment. Drug Deliv. 2017, 24, 162-180. [CrossRef]

42. Yang, J.; Sun, J.N.; An, X.J.; Zheng, M.X.; Lu, Z.X.; Lu, F.X.; Zhang, C. Preparation of ferulic acid-grafted chitosan using recombinant bacterial laccase and its application in mango preservation. RSC Adv. 2018, 8, 6759-6767. [CrossRef]

43. Vittorio, O.; Cojoc, M.; Curcio, M.; Spizzirri, U.G.; Hampel, S.; Nicoletta, F.P.; Iemma, F.; Dubrovska, A.; Kavallaris, M.; Cirillo, G. Polyphenol Conjugates by Immobilized Laccase: The Green Synthesis of Dextran-Catechin. Macromol. Chem. Phys. 2016, 217, 1488-1492. [CrossRef]

44. Sampaio, S.; Taddei, P.; Monti, P.; Buchert, J.; Freddi, G. Enzymatic grafting of chitosan onto Bombyx mori silk fibroin: Kinetic and IR vibrational studies. J. Biotechnol. 2005, 116, 21-33. [CrossRef] [PubMed]

45. Fertah, M.; Belfkira, A.; Dahmane, E.M.; Taourirte, M.; Brouillette, F. Extraction and characterization of sodium alginate from Moroccan Laminaria digitata brown seaweed. Arab. J. Chem. 2017, 10, S3707-S3714. [CrossRef]

46. Brus, J.; Urbanova, M.; Czernek, J.; Pavelkova, M.; Kubova, K.; Vyslouzil, J.; Abbrent, S.; Konefal, R.; Horsky, J.; Vetchy, D.; et al. Structure and Dynamics of Alginate Gels Cross-Linked by Polyvalent Ions Probed via Solid State NMR Spectroscopy. Biomacromolecules 2017, 18, 2478-2488. [CrossRef] [PubMed] 
47. Lopez-Martinez, L.M.; Santacruz-Ortega, H.; Navarro, R.E.; Sotelo-Mundo, R.R.; Gonzalez-Aguilar, G.A. A H-1 NMR Investigation of the Interaction between Phenolic Acids Found in Mango (Manguifera indica cv Ataulfo) and Papaya (Carica papaya cv Maradol) and 1,1-diphenyl-2-picrylhydrazyl (DPPH) Free Radicals. PLoS ONE 2015, 10, 0140242. [CrossRef] [PubMed]

48. Siddaramaiah; Swamy, T.M.M.; Ramaraj, B.; Lee, J.H. Sodium alginate and its blends with starch: Thermal and morphological properties. J. Appl. Polym. Sci. 2008, 109, 4075-4081. [CrossRef]

49. Nair, R.M.; Bindhu, B.; Reena, V.L. A polymer blend from Gum Arabic and Sodium Alginate-preparation and characterization. J. Polym. Res. 2020, 27, 154. [CrossRef]

50. Soares, J.P.; Santos, J.E.; Chierice, G.O.; Cavalheiro, E.T.G. Thermal behavior of alginic acid and its sodium salt. Eclet. Quim. 2004, 29,57-63. [CrossRef]

51. Di Luca, M.; Vittorio, O.; Cirillo, G.; Curcio, M.; Czuban, M.; Voli, F.; Farfalla, A.; Hampel, S.; Nicoletta, F.P.; Iemma, F. Electroresponsive graphene oxide hydrogels for skin bandages: The outcome of gelatin and trypsin immobilization. Int. J. Pharm. 2018, 546, 50-60. [CrossRef] [PubMed]

52. Pasquier, E.; Street, J.; Pouchy, C.; Carre, M.; Gifford, A.J.; Murray, J.; Norris, M.D.; Trahair, T.; Andre, N.; Kavallaris, M. Beta-blockers increase response to chemotherapy via direct antitumour and anti-angiogenic mechanisms in neuroblastoma. $\mathrm{Br}$. $\mathrm{J}$. Cancer 2013, 108, 2485-2494. [CrossRef] [PubMed]

53. Gogoi, N.; Chowdhury, D. Novel carbon dot coated alginate beads with superior stability, swelling and $\mathrm{pH}$ responsive drug delivery. J. Mater. Chem. B 2014, 2, 4089-4099. [CrossRef]

54. Saikia, A.K.; Aggarwal, S.; Mandal, U.K. Electrically induced swelling and methylene blue release behaviour of poly (Nisopropylacrylamide-co-acrylamido-2-methylpropyl sulphonic acid) hydrogels. Colloid Polym. Sci. 2015, 293, 3533-3544. [CrossRef]

55. Servant, A.; Bussy, C.; Al-Jamal, K.; Kostarelos, K. Design, engineering and structural integrity of electro-responsive carbon nanotube-based hydrogels for pulsatile drug release. J. Mater. Chem. B 2013, 1, 4593-4600. [CrossRef]

56. Tan, H.Q.; Jin, D.W.; Qu, X.; Liu, H.; Chen, X.; Yin, M.; Liu, C.S. A PEG-Lysozyme hydrogel harvests multiple functions as a fit-to-shape tissue sealant for internal-use of body. Biomaterials 2019, 192, 392-404. [CrossRef]

57. Yang, Y.W.; Zhang, C.N.; Cao, Y.J.; Qu, Y.X.; Li, T.Y.; Yang, T.G.; Geng, D.; Sun, Y.K. Bidirectional regulation of i-type lysozyme on cutaneous wound healing. Biomed. Pharm. 2020, 131, 110700. [CrossRef] [PubMed]

58. Ben Amara, C.; Degraeve, P.; Oulahal, N.; Gharsallaoui, A. pH-dependent complexation of lysozyme with low methoxyl (LM) pectin. Food Chem. 2017, 236, 127-133. [CrossRef] [PubMed]

59. Unagolla, J.M.; Jayasuriya, A.C. Drug transport mechanisms and in vitro release kinetics of vancomycin encapsulated chitosanalginate polyelectrolyte microparticles as a controlled drug delivery system. Eur. J. Pharm. Sci. 2018, 114, 199-209. [CrossRef] [PubMed]

60. Fermani, S.; Falini, G.; Minnucci, M.; Ripamonti, A. Protein crystallization on polymeric film surfaces. J. Cryst. Growth 2001, 224, 327-334. [CrossRef]

61. Liu, Y.X.; Wang, X.J.; Lu, J.; Ching, C.B. Influence of the roughness, topography, and physicochemical properties of chemically modified surfaces on the heterogeneous nucleation of protein crystals. J. Phys. Chem. B 2007, 111, 13971-13978. [CrossRef] [PubMed]

62. Escolano-Casado, G.; Contreras-Montoya, R.; Conejero-Muriel, M.; Castellvi, A.; Juanhuix, J.; Lopez-Lopez, M.T.; de Cienfuegos, L.A.; Gavira, J.A. Extending the pool of compatible peptide hydrogels for protein crystallization. Crystals 2019, 9, 244. [CrossRef]

63. Zare, M.; Sarkati, M.N.; Tashakkorian, H.; Partovi, R.; Rahaiee, S. Dextran-immobilized curcumin: An efficient agent against food pathogens and cancer cells. J. Bioact. Compat. Polym. 2019, 34, 309-320. [CrossRef]

64. Arts, M.J.T.J.; Dallinga, J.S.; Voss, H.P.; Haenen, G.R.M.M.; Bast, A. A new approach to assess the total antioxidant capacity using the TEAC assay. Food Chem. 2004, 88, 567-570. [CrossRef]

65. Li, Q.; Li, Q.; Tan, W.Q.; Zhang, J.J.; Guo, Z.Y. Phenolic-containing chitosan quaternary ammonium derivatives and their significantly enhanced antioxidant and antitumor properties. Carbohyd. Res. 2020, 498, 108169. [CrossRef] [PubMed]

66. Di Profio, G.; Curcio, E.; Cassetta, A.; Lamba, D.; Drioli, E. Membrane crystallization of lysozyme: Kinetic aspects. J. Cryst. Growth 2003, 257, 359-369. [CrossRef]

67. Li, G.P.; Xiang, Y.; Zhang, Y.; Wang, D.C. A simple and efficient innovation of the vapor-diffusion method for controlling nucleation and growth of large protein crystals. J. Appl. Cryst. 2001, 34, 388-391. [CrossRef]

68. Iranshahi, M.; Amanzadeh, Y. Rapid isocratic HPLC analysis of caffeic acid derivatives from Echinacea purpurea cultivated in Iran Chem. Nat. Compd. 2008, 44, 190-193. [CrossRef]

69. Pantuso, E.; Mastropietro, T.F.; Briuglia, M.L.; Gerard, C.J.J.; Curcio, E.; ter Horst, J.H.; Nicoletta, F.P.; Di Profio, G. On the Aggregation and Nucleation Mechanism of the Monoclonal Antibody Anti-CD20 Near Liquid-Liquid Phase Separation (LLPS). Sci. Rep. 2020, 10, 8902. [CrossRef] [PubMed]

70. Farinha, S.; Moura, C.; Afonso, M.D.; Henriques, J. Production of Lysozyme-PLGA-Loaded Microparticles for Controlled Release Using Hot-Melt Extrusion. AAPS PharmSciTech 2020, 21, 274. [CrossRef] 